\title{
English-Tibetan Dictionary of Modern \\ Tibetan
}




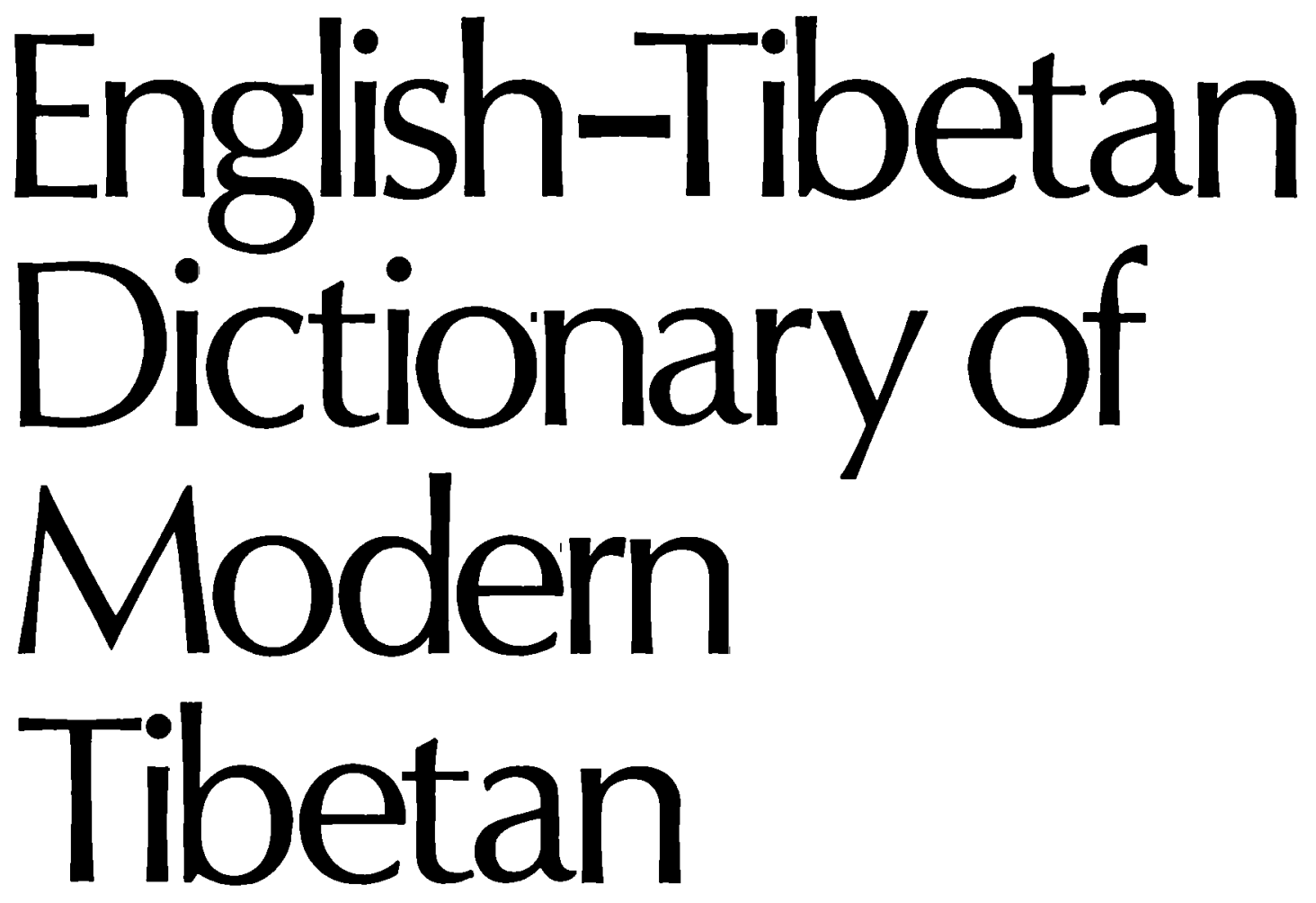

COMPILED BY

Melvyn C. Goldstein

WTH

Ngawangthondup Narkyid

UNIVERSITY OF CALIFORNIA PRESS

Berkeley · Los Angeles · London 
University of California Press

Berkeley and Los Angeles, California

University of California Press, Ltd.

London, England

(C) 1984 by

The Regents of the University of California

Printed in the United States of America

123456789

Library of Congress Cataloging in Publication Data

Coldstein, Melvyn C.

English-Tibetan dictionary of modern Tibetan.

1. English language-Dictionaries-Tibetan. I. Narkyid, Nganwangthondup. II. Title. $\begin{array}{llll}\text { PL3637.T52C65 } & 1984 & 423: 9541 & \text { 83-18119 }\end{array}$ ISBN 0-520-05157-2 